量線から求めたモル财光係数は $6.12 \times 10^{4} 1 \mathrm{~mol}^{-1} \mathrm{~cm}^{-1}$ であった。

\section{7 錯体の組成}

コバルトと ABNP の結合比を連続変化法及びモル比 法により求め $1: 3$ であることが分かった。

\section{8 共存イオンの影響}

コバルト $5 \mu \mathrm{g}$ について共存イオンの影響を調べた。 カリウム，ナトリウム，鉛，モリブデン(VI)， バリウ ム, カルシウムの各 $1000 \mu \mathrm{g}$, アルミニウム, クエン酸 塩, 酒石酸塩の各 $500 \mu \mathrm{g}$, カドミウム $200 \mu \mathrm{g}$, 銅(II) $100 \mu \mathrm{g}$ は妨害しなかった．クロム(III), マンガン(III), 鉄(II) は各 $25 \mu \mathrm{g}$ まで, ニッケル, 水銀(II) は $50 \mu \mathrm{g}$ までが妨害しなかった。

\section{9 他の方法との比較}

本法は, 感度の点では 2-ニトロソ-5-ジメチルアミ， フェノール7)，4-(2-ピリジルアゾ) レゾルシン8) 各抽出 光度法に匹敵し，1-ニトロソ-2-ナフトール抽出光度法6) よりも高い，しかし，生成錯体は 1-ニトロソ-2-ナフト ール錯体6)ほど安定なものではない。

$(1977$ 年 12 月, 日本薬学会 $)$ (九州支部例会において講演)

\section{交献}

1) A. Waksmundzki, S. Przeslakowski : Chem. Anal., 9, 69 (1964). (CA, 61, 20).

2) A. K. Singh, M. Katyal, K. G. Trikha, R. P. Singh : J. Indian Chem. Soc., 52, 891 (1975).

3) 土屋正臣, 佐々木洋興: 日化会誌, 1976, 1162.

4) 土屋正臣，佐々木洋興：同上，1977，1474.

5) 中島憲一郎, 平原裕久: 本誌, 26, 798 (1977).

6) 橋谷 博, 吉田秀世, 安達武雄 : 同上, 24, 452 (1975).

7) 桐栄恭二, 本水昌二 : 同上, 22, 1079 (1973).

8) 大河内春乃 : 同上, 21, 51 (1972).

$$
\text { זे }
$$

Determination of cobalt by spectrophotometry after solvent extraction with 6-amino-2-benzylthio-5-nitroso-4-oxo-3,4-dihydropyrimidine. Kenichiro Nakashima, Hirohisa Hirahara and Shuzo Akryama (Faculty of Pharmaceutical Sciences, Nagasaki University, 1-14, Bunkyo-machi, Nagasaki-shi, Nagasaki)

Spectrophotometric determination of cobalt after solvent extraction with 6-amino-2-benzylthio-5-nitroso4-oxo-3,4-dihydropyrimidine(ABNP) has been studied. ABNP easily reacts with cobalt forming a yellow complex which can be extracted with chloroform. The chloroform solution of the complex has an absorption maximum at $410 \mathrm{~nm}$ and shows a constant absorbance over the $\mathrm{pH}$ range of 2 to 6 . Beer's law is hold over the range of $(1 \sim 9) \mu \mathrm{g} / 10 \mathrm{ml}$ of cobalt at $410 \mathrm{~nm}(\varepsilon=$ $\left.6.12 \times 10^{4} 1 \mathrm{~cm}^{-1} \mathrm{~mol}^{-1}\right)$. The co-existence of less than $25 \mu \mathrm{g}$ each of chromium(III), iron(II) and manganese(II), and less than $50 \mu$ geach of nickel(II) and mercury(II) do not interfere with the determination. The established procedure is as follows. To a sample solution containing $(1 \sim 9) \mu \mathrm{g}$ of cobalt(II), are added $1 \mathrm{ml}$ of acetate buffer $(\mathrm{pH} 3)$ and $3 \mathrm{ml}$ of $0.01 \mathrm{M} \mathrm{ABNP}$-alcoholic solution. The mixture is diluted to $10 \mathrm{ml}$ with water and extracted with $10 \mathrm{ml}$ of chloroform. The chloroform solution is washed with $10 \mathrm{ml}$ of $3 \mathrm{M}$ hydrochloric acid and then with $10 \mathrm{ml}$ of water. The absorbance is measured at $410 \mathrm{~nm}$ against the reagent blank.

(Received Jan. 23, 1978)

\section{Keywords}

6-Amino-2-benzylthio-5-nitroso-4-oxo-3,4-dihydropyrimidine

Cobalt

Spectrophotometry

\section{ホウ酸半融法によるアルミナ質材料中}

\section{の酸化カルシゥムの定量}

板倉正勝*, 小玉数信**

(1978 年 2 月 25 日受理)

1 緒言

アルミナ質材料中の酸化カルシウムの定量は, 試料の 難分解性とともに試薬空試験や原子吸光分析における干 渉の問題があり，正確な定量値が得難い。

現在 JIS R 6123 「溶融アル之ナ研削材の化学分析法」 では, 炭酸ナトリウムとホウ酸で融解した後, 温水で抽 出し, 残さを塩酸に溶解, 更に中和して第 3 類水酸化物 を沪别, シュウ酸カルシウムとして沈殿させ, 重量法で 定量を行っている. このとき多量に使われる炭酸ナトリ ウム中に含まれる微量のカルシウムが問題となる・標準 試薬級を使わないと不正確となるが，高価であり，特級 試薬では正確な空試験值が得にくい。

著者らは同 JIS の酸化ナトリウムの定量に採用されて

*東芝セラミックス (株) : 愛知県刈谷市小垣江町南藤 1

** 名古屋工業大学 : 愛知県名古屋市昭和区御器所町 
いるホウ酸半融法1)を応用した. ただし温水抽出時に少 量の塩酸を添加することにより, 酸化カルシウム（及び 酸化マグネシウム）も抽出しうると考え, 実験を行った ところ, 前記の方法より簡単で同程度の精度を有する方 法として確立することができた.

\section{2 装置及び試薬}

\section{$2 \cdot 1$ 装}

原子吸光装置 : 日立 508 型. 使用条件は, 燃料, アセ チレン $0.8 \mathrm{~kg} / \mathrm{cm}^{2}-3.51 / \mathrm{min}$, 助燃ガス, 悪酸化窒素 $1.8 \mathrm{~kg} / \mathrm{cm}^{2}-6.51 / \mathrm{min}$ 中空陰極ランプ: 浜松 TV L-233 型 カルシウム単元素ランプー分析線 $422.7 \mathrm{~nm}$ $\mathrm{pH}$ メーター：堀場 $\mathrm{M}-7$ 型

\section{$2 \cdot 2$ 試 薬}

0.01 M EDTA 標準溶液: 同仁薬化学ドータイト $2 \mathrm{NA}$ $3.7 \mathrm{~g} / 1$ の溶液をつくり, 亜鉛標準溶液で標定した。

亜鉛 : 三津和化学薬品 (株) $99.999 \%$

無水炭酸ナトリウム: 旭硝子 (株) 製標準試薬

カルセイン, MTB (メチルチモールブルー) : 同仁薬 化学製品を硫酸カリウムと $1: 100$ の割合で混合

その他の試薬は特級品もしくは, 同等以上のものを使 用した。

\section{3 実験と考察}

\section{1 定量操作}

JIS R 6123 で採用されているホウ酸半融法は酸化ナ トリウム定量用のものであるから，これを以下のように 改めて酸化カルシウムの定量に応用した.

試料 $0.500 \mathrm{~g}$ を量り取り, めのう乳ばちで粉砕し, ホ ウ酸 $1.5 \mathrm{~g}$ を 3 回に分け良く混合し，かつ乳ばち中の試 料を完全に白金るつぼに移す.るつぼを徐々に（5〜10 分間）加熱し，あわが出なくなったら，5 分間強熱する. 冷却後 $200 \mathrm{ml}$ ビーカーに入れ, 水 $100 \mathrm{ml}$ と塩酸 $(1+$ 1) $0.5 \mathrm{ml}$ を加え, 熱板上で弱く煮沸する程度で約 30 分間抽出する.ガラス棒を用い，るつぼ壁に付着してい
る半融物をよく砕いた後, るつぼを洗って取り出す. 約 5 分煮沸後, 少量のろ紙パルプを加えてよく分散させ, No. 5B のろ紙でろ過し, 温水で十分洗浄する. 万液は $250 \mathrm{ml}$ のメスフラスコに移し，標線まで希釈して，試 料溶液とする. これより $100 \mathrm{ml}$ を分取し，アスコル ビン酸, トリエタノールアミン，シアン化カリウムを順 次加元，20\% 水酸化カリウム溶液を用いて $\mathrm{pH}$ を 12.8 に調整する $\{$ 最終液量は $(150 \sim 180) \mathrm{ml}$ 程度\}.カルセイ ン, MTB をおのおの, 耳かき 1 ぱい分ずつ指示薬とし て加光, 0.01 M EDTA 標準溶液で滴定する. 終点は緑色 けい光から無けい光暗とう色に変化する点である（横方 向からの照明で，黑色紙などを背景にすれば見やすい).

\section{2 抽出率の検討}

前記 $3 \cdot 1$ 操作における, 強熱時間と抽出時の塩酸の添 加量の変化による酸化カルシウムの抽出率を調べた結果 を Table 1 に示す. 試料 $0.5 \mathrm{~g}$, ホウ酸 $1.5 \mathrm{~g}$ で強熱 (5〜30) 分, 塩酸添加量 $(0.1 \sim 1.0) \mathrm{ml}$ の間で定量値の 変動以小さかった.

試料に対するホウ酸の量については 1:3 の比を中心 にして小幅な変動では問題なかったが，ホウ酸量を極端 に多くすると，融成物がスポンジ状にならず，温浸に よる溶解が困難であった. 以上の検討から各条件を前記 $2 \cdot 1$ 操作のように定めた.

\section{3 別法との比較}

次に同じ R 6123 の酸化カルシウムの定量法で得られ た值と上述の方法で得た值の比較を Table 2 に示す. ただし最終的にはシュウ酸塩として分離し重量法で定量 する代わりに, EDTA 滴定によった. Table 2 で示さ れるように両者の值は十分近似しており, 抽出後の残さ 中に残ることによるロスは絶対值としても小さく, カル シウム含有量の大きさにも特に考慮しなければならない ような影響は受けないと判断される。このように当ホウ 酸半融法は十分実用に供しうるここが分かった。

Table 1 Effect of sintering period and the amount of hydrochloric acid $\dagger$

\begin{tabular}{|c|c|c|c|c|c|c|}
\hline \multirow{2}{*}{$\begin{array}{l}\text { Sample A } \\
\text { taken (g) }\end{array}$} & \multirow{2}{*}{$\underset{(\mathrm{min})}{\text { Sintering time }}$} & \multirow{2}{*}{$\begin{array}{l}\mathrm{HCl}(1+1) \\
\text { added }(\mathrm{ml})\end{array}$} & \multicolumn{2}{|c|}{ By titrationt† } & \multirow{2}{*}{$\begin{array}{l}\text { By AAS }+ \text { tt } \\
\mathrm{CaO} \\
\text { found }(\%)\end{array}$} & \multirow{2}{*}{$\begin{array}{c}\mathrm{CaO}(\%) \text { inttlt } \\
\text { secondary } \\
\text { leached soln. }\end{array}$} \\
\hline & & & $\underset{(\mathrm{ml})}{M / 100 \text { EDTA }}$ & $\begin{array}{c}\mathrm{CaO} \\
\text { found }(\%)\end{array}$ & & \\
\hline 0.5253 & 5 & 0.1 & 0.50 & 0.106 & 0.105 & 0.005 \\
\hline 0.5313 & 10 & 0.2 & 0.45 & 0.095 & 0.116 & 0.004 \\
\hline 0.5116 & 15 & 0.5 & 0.46 & 0.102 & 0.120 & 0.004 \\
\hline 0.5094 & 30 & 1.0 & 0.51 & 0.113 & 0.113 & 0.006 \\
\hline
\end{tabular}

$\dagger$ Sintering with $1.5 \mathrm{~g}$ boric acid and leaching with $100 \mathrm{ml}$ hot water containing hydrochloric acid; $\dagger \dagger$ EDTA titration of a half of leached solution; t†† Atomic absorption spectrometry (AAS) of the leached solution; †t† The residue was leached again with hot water containing hydrochloric acid and calcium was determined by AAS. 
Table 2 Determination of calcium oxide in $\mathrm{Al}_{2} \mathrm{O}_{3}$ by present method and JIS method

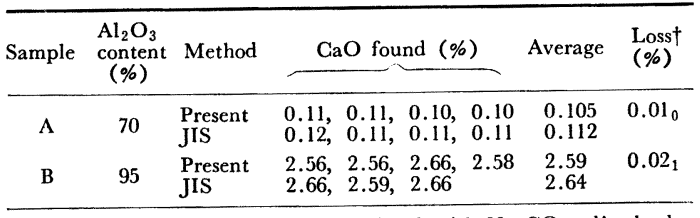

$\dagger$ The residue of the present was fused with $\mathrm{Na}_{2} \mathrm{CO}_{3}$, dissolved in $\mathrm{HCl}$, and determined by AAS.

\section{4 結語}

アルミナ質試料をホウ酸半融し，酸化ナトリウム定量 の場合には温水で抽出するところを，塩酸を添加するこ とにより酸化カルシウムもほとんど完全に抽出されるこ とが証明されたと考える。

この方法では，同一試料溶液から，ナトリウム，カリ ウム, カルシウムの定量が可能な外, データの提示を省 略したが, マグネシウムの定量も, その存在量とカルシウ ムとの比2) が適当であればキレート滴定で行うことがで きる.モデル混合試料について検討した結果によればマ グネシウムの滴定は，水酸化カリウムによって $\mathrm{pH}$ を 10.5 に調整し，イソプロピルアルコールを $1 / 2$ 容混合 し指示薬として TPG を使用する方法が終点（青色から ほとえど無色）の変色を見いだしやすい.

本法の別の利点としては試薬空試験のほとえどないデ 一タが得られるので，キレート滴定の代わりに原子吸光 法などを使用すれば，カルシウム，マグネシウムの含有 量の少ないときも正確な值が期待できる.

以上の点で本法は比較的短時間に簡単な操作でアルミ ナ質材料中の酸化カルシウムを定量する優れた方法と考 えられる.

なお，本研究で検討した試料は「東海無機分析化学研 究会」(ケイ酸塩部会) で採用された試料であり，同会 の数值を参考にさせて頂いたことを付記する.

\section{交献}

1) 小玉数信, 椎尾 - : 本誌, 9, 161 (1960).

2）上野景平: “キレート滴定法”，第 13 版，p. 224 (1969), (南江堂).

is

EDTA titration of calcium oxide in high-aluminous material after sintering with boric acid. Masakatsu ITAKurA* and Kazunobu KodAMA** (*Toshiba Ceramics Co., Ltd., 1, Minamihuzi, Ogakie-cho, Kariya-shi, Aichi; **Nagoya Institute of technology, Gokiso-cho, Showa-ku, Nagoya-shi, Aichi)

A $0.500 \mathrm{~g}$ sample is pulverized in an agate mortar, mixed with $1.5 \mathrm{~g}$ of boric acid and transferred into a platinum crucible. The mixture is heated gently for (5 10) $\mathrm{min}$, and ignited for $5 \mathrm{~min}$ after the bubbling has ceased. The crucible is gently boiled for $20 \mathrm{~min}$ in a $100 \mathrm{ml}$ water $-0.5 \mathrm{ml}$ hydrochloric acid $(1+1)$ mixture placed in a $200 \mathrm{ml}$ beaker. Crucible walls are rubbed with a glass rod, and the crucible is taken away. The solution is boiled for $5 \mathrm{~min}$, filtered through No. 5B filter paper together with a small amount of filter pulb, and diluted to $250 \mathrm{ml}$ with water. To a $100 \mathrm{ml}$ aliquot is added a small amount of ascorbic acid, triethanolamine, potassium cyanide, 20\% potassium hydroxide (to give a $\mathrm{pH} 12.8$ ), and finally about $10 \mathrm{mg}$ each of calcein and methylthymol blue (both $\left.1: 100 \mathrm{~K}_{2} \mathrm{SO}_{4}\right)$. Calcium in the aliquot is determined volumetrically with $0.01 \mathrm{M}$ EDTA (from green fluorescence to dark orange). The analytical results agreed well with those by JIS method, but the present method is simpler because the calcium oxide blank in sodium carbonate used in JIS method is difficult to correct. If necessary, magnesium, sodium, and potassium can also be determined.

(Received Feb. 25, 1978)

\section{Keywords}

Boric acid

Calcium oxide

EDTA titration

High alumina material

Sintering 